\title{
The effect of high-performance work systems according to AMO model on HRM performance outcomes: An analytical study on the banking sector
}

\author{
Fatimah Mohamed Mahdy ${ }^{a, b^{*}}$ and Asia Yagoub Alhadi ${ }^{a}$
}

${ }^{a}$ Business administration, College of business, King Khalid University, Abha, Saudi Arabia ${ }^{b}$ Business administration, Faculty of commerce, Suez University, Suez, Egypt

C H R O N I C L E

\begin{tabular}{l} 
Article history: \\
Received: December 12, 2020 \\
Received in revised format: \\
December 292020 \\
Accepted: February 14, 2021 \\
Available online: \\
February 14, 2021 \\
\hline Keywords: \\
High-Performance Business Sys- \\
tems (HPWS) \\
AMO Model \\
HRM Performance outcome
\end{tabular}

A B S T R A C T

\begin{abstract}
This research paper aims to study the impact of high-performance work systems (HPWS) according to the AMO includes three human resource management practices which are (Ability-enhancing human resource management practices, motivation-enhancing human resource management practices, and opportunities -enhancing human resource management practices). The authors select a random sample of 400 individuals from 10 banks in Saudi Arabia, Egypt, Sudan to prove the validity of the hypotheses; The study found a set of results and one of them indicate that there is a significant positive relationship among high-performance work systems according to the AMO model on the results of human resource performance.
\end{abstract}

\section{Introduction}

In a dynamic environment, organizations are continually striving to achieve a competitive advantage that secures their sustainability and survival. Many researchers in various fields have emphasized that a continuous competitive advantage can only be achieved when the organization possesses valuable, scarce, imitation, non-exchangeable, and non-transferable resources. Human resources are essential resources (Jyoti \& Rani 2019), that organizations possess to achieve the required competitive advantage. Thus, researchers and practitioners have devoted a great deal of time and efforts to study all possible means to make the most of their human resources, and one of the most important efforts is the invitation Guest, 1997 To refine the theory regarding how human resources management is linked to performance (Almutawa, Muenjohn \& Zhang 2016), from here emerged modern management concepts, methods and approaches in the field of human resource management, including high-performance work systems (HPWS) according to the Ability, Motivation, Opportunity model. The authors found that most of the studies on high-performance HR practices have been conducted in developed countries (Muduli, 2015; Posthuma, Campion, Masimova, Michael \& Campion, 2013) and that there is a real dearth of application of these practices in developing countries, especially the Arab world. Although recent literature of HPWS and AMO model have consolidated the prominent role of HRM, we still lack a theoretical understanding of how to link this with HRM performance outcomes. The literature to date has not fully considered integrating HPWS according to the AMO model and HRM performance outcomes. For example, there are several papers Separately have identified the effect of HPWS (e.g., Kloutsiniotis \&Mihail, 2020; Baik, Kim \& Patel,2019; Jyoti \& Rani, 2019), On the other side there are papers Separately have focused on AMO model (e.g., Al-tit,2020; $\mathrm{Li}, \mathrm{Xu}$, Ghen \& Menassa, 2019). Conversely, many papers have used the AMO model as an intermediate variable (e.g., Martin \& Liusar, 2018). Finally, there are theoretical articles have linked HPWS and AMO but did not measure the outcomes of HRM performance (e.g. Nehles, Riemdijk, \& Louise, 2013; Edgar, Blaker, \& Everett, 2020; Ozcelik \& Uyargil,2015). Consequently, this study investigates the following crucial research questions (RQs):

* Corresponding author. Tel.: +9660597522610

E-mail address: fmhassan@kku.edu.sa (F. M. Mahdy) 
RQ(1). Do high-performance work systems (HPWS) according to AMO model, affect HRM Performance Outcomes?

RQ (2). Do Ability Enhancing HRM Practices affect HRM Performance Outcomes?

RQ (2). Do Motivation Enhancing HRM Practices affect HRM Performance Outcomes?

RQ (2). Do Opportunities Enhancing HRM Practices affect HRM Performance Outcomes?

\section{Theory and literature review}

\subsection{High-Performance Work Systems (HPWS)}

Over the past three decades, there has been an immense amount of research linking human resource (HR) practices with positive organizational performance (Messersmith \& Guthrie, 2010). The most common term that characterizes such a relationship is High-Performance Work Systems (HPWS). They are also referred to in the literature as High Commitment Management, Highly Participatory Management, or Innovative Business Practices (Moriones, 2010; García \& Conci, 2012). The roots of the concept of HPWS extend back to the late twentieth century, during the turmoil of the industrial sector in the United States that recognized During that period, the importance of global competition and the need to truly rethink manufacturing processes (Jyoti \& Rani, 2017). HPWS is still at the forefront of the HRM literature in general. According to Jyoti and Rani (2017), HPWS has been defined as the organizational structure that brings together work, people, technology, and information to produce high performance in response to customer requirements and other environmental opportunities. HPWS is a coherent HR practice system supposed to improve organizational performance by improving employee skills, motivation, and the opportunity to participate in the work (Appelbaum, Berg, Bailey \& Kalleberg, 2000). Hoque, Wass, Bacon \& Jones, (2018) added that HPWS is a specific combination of Human resource practices, work structures, and processes that maximize employee knowledge, skills, flexibility, and commitment.

\subsection{Models (dimensions) of HPWS practices}

There is no consensus in most studies of high-performance work systems about the best model for HPWS practices and its relationship to HRM. For example, Chuang and Liao (2010) defined it as having six sub-dimensions (recruitment, training, participation/participation, performance appraisal, compensation/rewards, and sponsorship) that measure 35 components. Demirbag, Collings, Tatoglu, Mellahi \& Wood. (2014) divided practices into seven dimensions of the seven as a key to the success of HPWS: job security, selective recruitment of new employees, self-managed teams, decentralization of decisionmaking, relatively high compensation that depends on organizational performance, intensive training, and reducing differences between situations, including Staff uniform, language, office arrangements, and sharing of financial and performance information throughout the organization. Gittell, Seidner \&Wimbush (2010) measured HPWS using six sub-dimensions (Selection, Conflict Resolution, Performance Measurement, Rewards, Meetings), HPWS measures using six dimensions (selective recruitment, participation in decision-making through teams, and remuneration) Relatively high-performance dependent, intensive training, career planning and advancement, and regular performance appraisal of wages, promotion and development purposes (Gong, Chang \& Cheung 2010; Zacharatos, Barling \& Iverson, 2005) proposed a set of 10 practices containing 63 components for measuring HPWS) Job security, selective recruitment, extensive training, teams, decentralized decision-making, low discrimination of status, information sharing, contingency compensation, transformational leadership, high-quality work, and measurement of managerial practices). Finally, HPWS practices are measured with the AMO model, including three main dimensions (Ability, motivation, and participation opportunities. This existing research will address the last measure and study its impact on HRM management performance outcomes.

\subsection{Ability, motivation, opportunities (AMO) model}

The AMO model explains its expected, actual and perceived HRM practices, adopting an employee-based perspective to link the opportunity to motivate individuals' ability when implementing HRM practices with company performance (Appelbaum, Bailey, Berg, Kalleberg \& Bailey, 2000). Whereas, the AMO model (Nehles, Riemsdijk \& Looise, 2013) takes a management perspective that focuses on line managers' ability to implement HR practices, their drive to empower them, and the organizational support to make the necessary changes (O) (Ozcelik \& Uyargil, 2015). based on Theoretical discourse among industrial and social psychologists to determine the dimensions of performance in organizations, industrial psychologists assume that performance is a function of training and selection (ability). On the other hand, social psychologists believe that motivation is necessary to ensure performance (Edgar, Zhang \& Nancy, 2020). in Vroom's (1964) theory interpret performance estimation through the function that explained the interactive relationship takes into account both ability and motivation $\{\mathrm{P}=\mathrm{f}(\mathrm{A} \times \mathrm{M})$ \}(Garcia, \& Tomas), as it is evident from the previous equation that only personality dimensions affect performance, And was unable to explain the influence of the external environment. To solve this problem, Blumberg and Pringle (1982) developed a new paradigm, which broadens the concepts of motivation and ability, and offers a new paradigm: opportunity, which they considered the missing dimension. As a result, the performance was a function of the ability to perform including various variables such as age, knowledge, education level, and energy, willingness to perform including variables such as motivation, job satisfaction, personality, values, and expectations, and performance opportunity which included variables such as work conditions and tools, materials, leader behavior, actions, and time. These authors indicated that the three elements (opportunity, ability, and desire) must be present for performance to occur (Garcia \& Tomas, 2016). After presenting all these 
explanations and the efforts of the researchers, The AMO emerged as a model at the hands of Bailey,1993 and developed with contributions (Appelbaum et al. 2000), in which it suggested that ensuring the discretionary effort of an employee needs three components: The employees must have the necessary skills, need the appropriate motivation, and the owners must have: Work is to offer them the opportunity to participate, based on this model, and its abbreviation symbolizes the three elements that enhance the employee's performance together: individual ability (A), motivation (M), and the opportunity to participate (O) (Ozcelik \& Uyargil ( 2015). : $\{\mathrm{P}=\mathrm{f}(\mathrm{A} \times \mathrm{M} \times \mathrm{O})\}$, meaning that performance depends on the individual's ability, motivation and opportunity. Individuals perform when they have, the ability (A) to perform (they can do the task because they have the necessary knowledge, skills and abilities); motivation (M) to perform (They will do the task because they want to do it or feel they must do it), and the opportunity $(\times)$ to perform (their work structure and environment provide necessary support and ways of expression) (Armstrong \& Brown, 2019). Armstrong and Brown (2019) efficiency can be defined as knowledge. Furthermore, the skills and abilities that individual employees possess, and are closely related to building competency a Professional Autonomy (Knies \& Leisink, 2014), which defined as employees' evaluation of their competencies in successfully performing their jobs. A motivation or motivation can be defined (as "the degree to which an individual wants and chooses to engage in certain specific behaviors" (Kim et al., 2015). Motivation can be external or intrinsic (García \& Miralles, 2011). External factors are associated with incentives such as economic rewards. They usually focus on short-term gains, while intrinsic factors emerge from an individual's interests and values, such as when a person finds a satisfying and enjoyable job (Minbaeva, 2013). Internal motivation is usually associated with an employee's long-term commitment (Schimansky, 2014) While the 'Ability' dimension focuses on employees' ability to contribute, the "motivation" dimension deals with how keen they are to use these ability linkages (Liao et al., 2009). Finally, the dimension (O) reflects how they can Transform employees' abilities and efforts into outcomes (Jiang et al., 2013). Opportunity can also be defined as a set of conditions that make it possible to do something. Employees' opportunity to participate has many dimensions, such as participation in the decisionmaking process, knowledge exchange, and communication. Horizontal and Job (Enrichment Schimansky, 2014).

\subsection{Ability, Motivation and Opportunity Enhancing HRM Practices and HPWS}

In many studies, the quality of HRM is measured by evaluating the HRM practices that the company has (Wright, Dunford \& Snell,2001). HRM practices associated with employee ability development are specifically recruitment, selection, training and development policies. (Jiang et al. 2012), various studies have attempted to link these ability improvement practices to different organizational outcomes. In general, it links high-performance work systems (HPWS) that enhance capabilities positively by developing their additional skills and roles in (Sánchez \& Susana 2019).

\subsubsection{Ability-Enhancing HRM Practices}

The ability enhancement dimension reflects the degree of investment in human resource practices to improve the knowledge, skills, and abilities (KSA) of employees (Wright and Kehoe, 2008). HR practices in recruitment and training directly affect employees' ability to perform by affecting their stock in knowledge skills ability (Katou \& Budhwar, 2010). Consequently, ability-enhancing HRM practices are those that affect workers' competencies through recruitment, selection, training, and development and increase employee capabilities and competencies to achieve organizational goals. (Guerci et al., 2015; Gardner, Wright \& Moynihan, 2011; Jiang et al., 2012). Recruitment and selection practices have been sought to ensure that prospective employees are researched and appropriate personnel matched with skills and competencies for specific job requirements. Hence, recruitment and selection are likely to enhance the highly skilled workforce by attracting and selecting employees with higher levels of knowledge and skills relevant to the organizations.

\subsubsection{Motivation- Enhancing HRM Practices}

Motivation enhancement is the degree of investment in human resource practices that motivate employee behavior (Wright \& Kehoe, 2013). Kehoe and Wright (2013) view motivation-enhancing practices as rewards based on individual and group performance outcomes, and formal performance evaluation mechanisms, And merit-based promotion systems. All these practices seek to improve employee motivation and enhance their efforts to achieve goals and enhance performance. Some practices related to motivation enhancement have a more significant impact on external motivations, such as performance appraisal, external incentives, payment for performance (individual), payment for performance (group level), job security, internal promotion, social activities, and opportunities for life-to-work balance. On the other hand, practices associated with intrinsic motivation are motivated to learn (Sterling \& Boxall. (2013)), personal or group satisfaction (Drummond \& Stone, 2007), Collaborative climate (Kim et al. 2015).

\subsubsection{Opportunity- Enhancing HRM Practices}

Opportunities enhancing to delegate decision-making power and enhance employee voice (Demortier, Delobbe \& Akremi, 2014). Hence, participation is seen as an opportunity for employees to participate. García, Bayarri, \& Huerta. (2015) Opportunity-enhancing practices can group into four main packages: employee engagement practices, knowledge-sharing practices, job design practices, and autonomy-promoting practices. Employee engagement practices include quality circles, self-directed work teams, problem-solving teams, teamwork, and those practices that reinforce sequences-hierarchy and participation in the decision-making process. Knowledge sharing practices aim to provide adequate information about critical issues within 
the organization (performance, financial, operating or strategic information) (Demortier et al., 2014). These practices also aim to ensure communication between employees and management. Several authors agree that information exchange and communication are essential to improving the opportunity enhancement dimension. Besides, many authors also consider those practices designed to enhance employee voice, such as suggestion systems, complaints systems, or questionnaires, to be necessary. Job design practices include appropriate job description (practices, procedures and workplace design), support from HR professionals, job rotation, internationalization level, and provision of favorable working conditions (García, Bayarri, \& Huerta 2015).

\subsection{HRM performance outcomes}

Performance is defined in different ways in different strands of the literature. The performance indicators to be used in relation to the effectiveness of HRM are still a matter of debate. Several criteria are used to measure performance such as specific HRM outcomes, behavioral outcomes at the individual or group level, or performance outcomes (for example, profit or sales) at the department or even company level (Jiang et al., 2012). Define work performance theory (Cummings \& Schwab, 1973). Performance as a behavior related to fulfilling the requirements of the expected, specified or official role on the part of individual members of the organization. The outcomes of organizations' performance can be divided into two main types, which are operational outcomes and include return on assets, sales growth, job performance, productivity/efficiency, product quality / Service, HRM effectiveness, customer satisfaction (Garcia \& Tomas, 2016), human resource outcomes and include (employee turnover intent, trust in management, job satisfaction, enterprise citizenship behavior, absenteeism, innovative behavior, employee commitment, retention. Employees, organizational climate) (Garcia \& Tomas, 2016), in this study, our goal is not to measure the overall performance of the organization as a whole, but to measure the performance of human resources. Therefore, HR outcomes were relied upon to measure performance. From the above, the study hypotheses can be formulated as follows:

The main hypothesis of the research (H1): There is a statistically significant effect among high-performance work systems according to the (AMO) model on the HRM performance outcomes.

A number of sub-hypotheses emerge from the main hypothesis, namely:

H1.1: There is a statistically significant impact between the ability-enhancing HRM practices (training and development, recruitment and selection, performance evaluation) on the HRM performance outcomes.

H1.2: There is a statistically significant impact between motivation -enhancing HRM practices (material incentives, job promotion, cooperative climate, job security on the HRM performance outcomes.

H1.3: There is a statistically significant impact between opportunity-enhancing HRM practices (quality circles, group work, decision-making, information exchange and communication, job title, job rotation) on the HRM performance outcomes.

\section{Methodology}

\subsection{Sample and data collection}

In this research, two basic methods have been adopted: the theoretical study by viewing the published research, and the analytical study by designing a questionnaire that includes the research variables. The authors chose the banking sector to implement their study as this society chose due to its importance in achieving stability and economic development in a changing world. The primary and national banks were chosen in Saudi Arabia, Egypt and Sudan, and the sample included ten banks (See Table 1).

Table 1

Sample Characteristics of respondents $(n=375)$

\begin{tabular}{|c|c|c|c|c|c|}
\hline Bank name & $\mathrm{N}$ of branches & $\mathrm{N}$ of Employees & $\begin{array}{c}\mathrm{N} \text { of hr employees and } \\
\text { managers }\end{array}$ & $\mathrm{N}$ of sample & $\%$ of sample \\
\hline \multicolumn{6}{|l|}{ Egyptian banks } \\
\hline National Bank of Egypt & 510 & 14000 & 1750 & \multirow{3}{*}{140} & \multirow{3}{*}{$35 \%$} \\
\hline CIB Bank & 202 & 6800 & 634 & & \\
\hline Bank of Alexandria & 171 & 5000 & 436 & & \\
\hline \multicolumn{6}{|l|}{ Saudi banks } \\
\hline Al -Rajhi Bank & 500 & 13896 & 5300 & \multirow[t]{3}{*}{180} & \multirow[t]{3}{*}{$45 \%$} \\
\hline Riyadh Bank & 308 & 7115 & 600 & & \\
\hline Arab National Bank & 197 & 4607 & 218 & & \\
\hline \multicolumn{6}{|l|}{ Sudanese banks } \\
\hline Faisal Islamic Bank & 31 & 355 & 62 & \multirow{4}{*}{80} & $20 \%$ \\
\hline Al Baraka Bank & 25 & 318 & 41 & & \\
\hline Sunny Blue Nile Bank & 10 & 132 & 13 & & \\
\hline Omdurman Bank & 18 & 614 & 19 & & \\
\hline Total & & & 9073 & 400 & 100 \\
\hline
\end{tabular}


Given the difficulty of collecting data as a comprehensive and challenging inventory Reaching all the study items, a similar random sample of 400 items was selected, 400 questionnaires were distributed to the selected banks, 375 correct items were retrieved at a rate of $93.75 \%$.

\subsection{Variables and measurement}

The independent variable (high-performance work systems according to the AMO model) was measured through three dimensions: ability, motivation, and opportunities to participate through 42 elements that were adopted based on the research theory and review of the relevant literature. Fourteen different HRM practices were measured. And it was as follows in detail: Factors of the independent variable (Ability, Motivation, Opportunity, Participation Opportunities), the ability factor was measured through three HRM practices, namely (Training and Development, Recruitment and Selection, and Performance Appraisal) that included ten elements, while the motivation factor was measured through 4 management practices Human resources are (material incentives, job promotion, cooperative climate, job security), which included 14 elements, and finally the participation opportunity factor, which was measured through six HRM practices (quality circles, teamwork, participation in the decision-making process, information and data exchange, Job title, job rotation), included 18 elements. On the other hand, the dependent variable (HRM performance outcomes) was measured through 18 elements that included six factors: (employee turnover intent, job satisfaction, citizenship behavior of the organization (OCB), absence Employee commitment, employee retention). Respondents were asked to respond using a five-point Likert-type scale, ranging from 1 "no plan to implement" to 5 "full implementation".

Table 2

Exploratory Factor Analysis Results

\begin{tabular}{|c|c|c|c|c|c|}
\hline Measurement items & $\begin{array}{l}\text { Factor } \\
\text { loadings }\end{array}$ & t-value & $\begin{array}{l}\text { Cronbach's } \\
\text { Alpha }\end{array}$ & $\mathrm{CR}$ & AVE \\
\hline \multicolumn{3}{|l|}{ Ability- Enhancing HRM Practices(A) } & \multirow{10}{*}{ O.815 } & \multirow{10}{*}{0.843} & \multirow{10}{*}{0.354} \\
\hline Employees are recruited based on the bank's needs. & 0.445 & 3.97 & & & \\
\hline The recruitment of bank employees based on objective foundations. & 0.549 & 3.75 & & & \\
\hline Selection and appointment policies are consistent with the bank's objectives. & 0.434 & 3.84 & & & \\
\hline The bank follows up with employees after completing the training to ensure that their knowledge applied in their jobs. & 0.488 & 3.83 & & & \\
\hline The bank determines the training needs according to a pre-set plan. & 0.478 & 3.92 & & & \\
\hline New employees trained to know the nature of work before practicing their work tasks. & 0.465 & 3.94 & & & \\
\hline Future training courses are determined based on the actual needs of workers. & 0.444 & 4.06 & & & \\
\hline The bank's performance evaluation system is appropriate. & 0.468 & 3.95 & & & \\
\hline The performance appraisal system is an effective system that helps in developing employee performance. & 0.434 & 4.87 & & & \\
\hline \multicolumn{3}{|l|}{ Motivation - Enhancing HRM Practices(M) } & \multirow{13}{*}{0.845} & \multirow{13}{*}{0.862} & \multirow{13}{*}{0.423} \\
\hline The bank awards rewards and incentives based on objective criteria. & 0.535 & 4.02 & & & \\
\hline Giving employees incentives is linked to their job performance levels. & 0.539 & 3.96 & & & \\
\hline The administration takes care of the moral aspect and raising morale. & 0.484 & 3.9 & & & \\
\hline The bank provides employees with career development opportunities. & 0.5 & 3.96 & & & \\
\hline The bank's employees are promoted based on the results of their performance evaluation. & 0.461 & 4 & & & \\
\hline The promotion laws are applied fairly and objectively. & 0.552 & 4.02 & & & \\
\hline Graduating in my current job increases my bond with the bank. & 0.498 & 3.8 & & & \\
\hline I am sure that I will not fire without justification. & 0.549 & 3.87 & & & \\
\hline The bank is keen not to distinguish between employees. & 0.419 & 3.99 & & & \\
\hline I assure of my future career in the bank. & 0.555 & 4 & & & \\
\hline I can submit a complaint to the officials of the bank without worries. & 0.542 & 3.99 & & & \\
\hline I think the bank offers me privileges that I cannot find elsewhere. & 0.423 & 3.9 & & & \\
\hline \multicolumn{3}{|l|}{ Opportunity - Enhancing HRM Practices $(\mathrm{O})$} & \multirow{15}{*}{0.811} & \multirow{15}{*}{0.827} & \multirow{15}{*}{0.416} \\
\hline Top management is keen to involve all employees in making business decisions. & 0.422 & 3.89 & & & \\
\hline The evaluation criteria in the bank take into account the opinions of colleagues. & 0.531 & 3.85 & & & \\
\hline I use what I learned about group development and cooperation to help my community become effective. & 0.425 & 3.85 & & & \\
\hline The goals of my department are clear to the members. & 0.454 & 3.79 & & & \\
\hline The department applies its decision at work, which generates a spirit of innovation and innovation at work. & 0.43 & 3.76 & & & \\
\hline $\begin{array}{l}\text { Strengthening the behavioral commitment of the department members contributes to increasing the under- } \\
\text { standing between them. }\end{array}$ & 0.457 & 4.08 & & & \\
\hline We get feedback on our performance. & 0.455 & 3.96 & & & \\
\hline The confidence I feel from my immediate boss makes me do better. & 0.426 & 3.98 & & & \\
\hline Knowledge sharing stimulates the generation of entrepreneurial and innovative ideas. & 0.429 & 3.86 & & & \\
\hline Employees understand the importance of implementing quality. & 0.558 & 3.99 & & & \\
\hline The employees are fully aware of the bank's quality policy based on customer satisfaction and continuous improvement. & 0.58 & 3.99 & & & \\
\hline The job requirements in the bank change periodically depending on the business requirements. & 0.618 & 4 & & & \\
\hline The bank is expanding the business horizontally by adding new responsibilities. & 0.642 & 4.09 & & & \\
\hline $\begin{array}{l}\text { An excellent organizational climate created during job rotation, which facilitates the transfer and exchange } \\
\text { of managerial skills and knowledge for employees }\end{array}$ & 0.672 & 4.02 & & & \\
\hline \multicolumn{3}{|l|}{ HRM performance outcomes } & \multirow{12}{*}{0.849} & \multirow{12}{*}{0.855} & \multirow{12}{*}{0.371} \\
\hline My survival in my current job based on my desire to continue working & 0.654 & 4.07 & & & \\
\hline Management allows employees to exercise responsibilities and powers to an adequate level & 0.621 & 4.15 & & & \\
\hline Receive the respect and appreciation of the management & 0.718 & 4.26 & & & \\
\hline The bank seeks to determine the prevailing business values continuously & 0.691 & 4.27 & & & \\
\hline The company instils positive behavioral values among employees, which affect their level of commitment to work & 0.459 & 4.37 & & & \\
\hline I rarely miss my job & 0.46 & 4.39 & & & \\
\hline The work environment motivated me to discipline my work. & 0.453 & 4.21 & & & \\
\hline I participate in the bank's voluntary development activities. & 0.429 & 4.43 & & & \\
\hline I inform new workers about the regulations to work. & 0.558 & 4.27 & & & \\
\hline I encourage my colleagues to express their views on issues related to my job. & 0.572 & 4.28 & & & \\
\hline The recruitment of bank employees based on objective foundations & 0.653 & 4.52 & & & \\
\hline
\end{tabular}




\subsection{Reliability and Exploratory Factor Analysis}

To evaluate each theoretical construct's reliability, we assessed construct reliability by performing EFA to ensure the scale items' unidimensionality. This step is a cautious procedure that helps assess the structure of the factors. It is necessary because we adapted existing scales to the banking sector. We conducted a principal component analysis with varimax rotation to identify the theoretical constructs' underlying dimensions. As illustrated in Table 2, the factor analysis shows that three factors were extracted that included 46 elements and 14 elements with a loading factor less than 0.40 were excluded, with eigenvalues greater to improve the strength of factors and the measurement items all had strong loadings on the construct that they intended to measure. Thus, we conclude that the unidimensionality of the constructs is confirmed. Conversely, Cronbach's alpha and composite reliability (CR) calculated to assess each theoretical construct's reliability. Results show that the Cronbach's alpha and $\mathrm{CR}$ of all the constructs were above the widely-recognized rule of thumb of 0.70 . In addition, the average variance extracted (AVE) of each construct was less than the value of 0.50 , indicating strong convergent validity and the constructs and scales have convergent validity. Eventually, the results showed that the KMO value $=0.771$ indicating a worthy level based on Kaiser and Rice (1974) and Bartlett's pupil test was significant $(\chi 2=887, \mathrm{p}=0.00)$.

\subsection{Confirmatory factor analysis CFA}

The validity of the measurement model for the previous factors was evaluated through confirmatory factor analysis using SEM structural modelling methods using Amos software (v22, Amos). The aim of using the structural equation modelling (SEM) program is to determine the extent to which the theoretical model matches the field data collected by the selected sample. If the sample data support the theoretical model, then it is possible to assume more complex theoretical models, but if the field data does not support the theoretical model Either the original model is modified and tested, or other theoretical models are developed and tested, the fit of the model was assessed using various combinations of fitness indicators including the standard chi-square, the RMSEA approximation, the CFI, and the NFI. And standard root means square remaining SRMR, standard fit index. Accordingly, the suggested motivation factor fits the data well $(2=177.620, \mathrm{p}$-value $=.00234,0, \chi 2 / \mathrm{df}=$ $1.023, \mathrm{CFI}=.919, \mathrm{TLI}=.934, \mathrm{NFI}=0.946, \mathrm{RMSEA}=.047)$. Regarding the proposed motive factor $(\chi 2=246.988, \mathrm{p}$-value $=.0042, \chi 2 / \mathrm{df}=1.57, \mathrm{CFI}=.900, \mathrm{TLI}=.954, \mathrm{NFI}=0.966, \mathrm{RMSEA}=.032$,$) . As for the participation chances factor, its$ data were as follows $(2=273.001, \mathrm{p}$-value $=.0065,2 / \mathrm{df}=1.22, \mathrm{CFI}=.912, \mathrm{TLI}=.913, \mathrm{NFI}=0.931, \mathrm{RMSEA}=.026)$. The dependent variable (HRM performance outcomes), the variable was measured through 18 elements that included 6 factors, they are (employee turnover intent, job satisfaction, citizenship behavior for the organization (OCB), absence, employee commitment, employee retention). The sample data were as follows $(2=309.791, \mathrm{p}$-value $=.0041,2 / \mathrm{df}=1.67, \mathrm{CFI}=.988, \mathrm{TLI}$ $=.991, \mathrm{NFI}=0.973, \mathrm{RMSEA}=.018)$. This step is followed by testing the validity of the measurement of the proposed model as a whole, in this step a theoretical model is developed that explains the relationships between the research variables (the independent variable, the dependent variable) as in the following Fig 1.

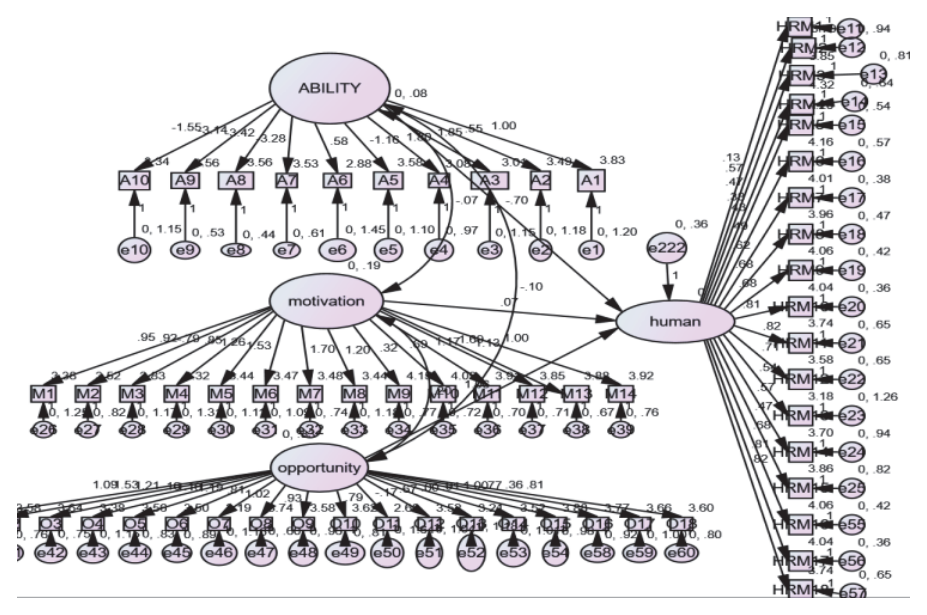

Table 3

Data analysis of model before modification

\begin{tabular}{ll}
\hline hi-square & $\mathbf{2 7 4 8 . 8}$ \\
\hline df & 534 \\
CMIN / DF & 2.385 \\
RMSEA & .068 \\
RMR & .206 \\
NFI ,IFI, TLI & $.673, .724, .534$ \\
CFI, GFI, AGFI & $.692, .666, .691$ \\
\hline
\end{tabular}

Fig. 1. The interpretive structural equation model of HPWS in the HRM performance outcomes Before modification $(\mathrm{P} * * *)$

It is evident from the previous data that the construction model does not match the data, as most of the matching statistics did not fall in the acceptable range, which indicates that the model does not match the data. Accordingly, this form must be amended to achieve a good match. And that by reviewing and deleting the most visible variables that have been proven weak, 
unrelated or divergent on the building model to which they belong. To become the general model of the study in Fig. 2, and the results change to the following:

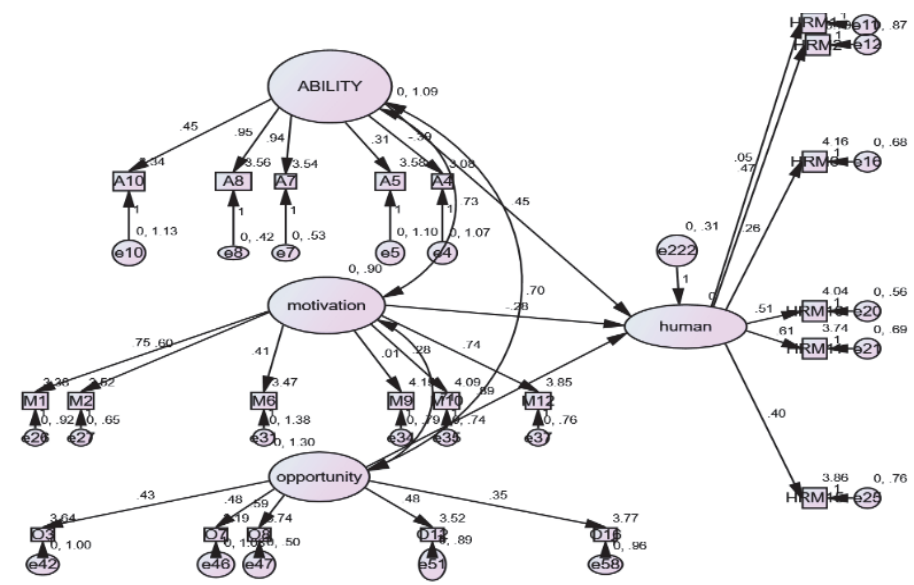

Table 4

Data analysis of model after modification

\begin{tabular}{ll}
\hline hi-square & 320,16 \\
\hline df & 99 \\
CMIN / DF & 1.275 \\
RMSEA & .052 \\
RMR & .194 \\
NFI ,IFI, TLI & $.952, .911, .925$ \\
CFI , GFI, AGFI & $.962, .935, .914$ \\
\hline
\end{tabular}

Fig. 2. The interpretive structural equation model of HPWS in the HRM performance outcomes after modification $(\mathrm{P} * * *)$

Fig 2 illustrates that the revised building model is the best solution as the value of hi-square is not significant, which means that there are no differences between the field data and this modified model, and all its matching statistics came in the acceptable range, which indicates that the model explains the data of the current study more effective.

\subsection{Hypothesis analysis}

The following fig 4 shows the nature of the relationship between each of the independent variables and the dependent variable in terms of direct and inverse relationship, positive, negative and significant

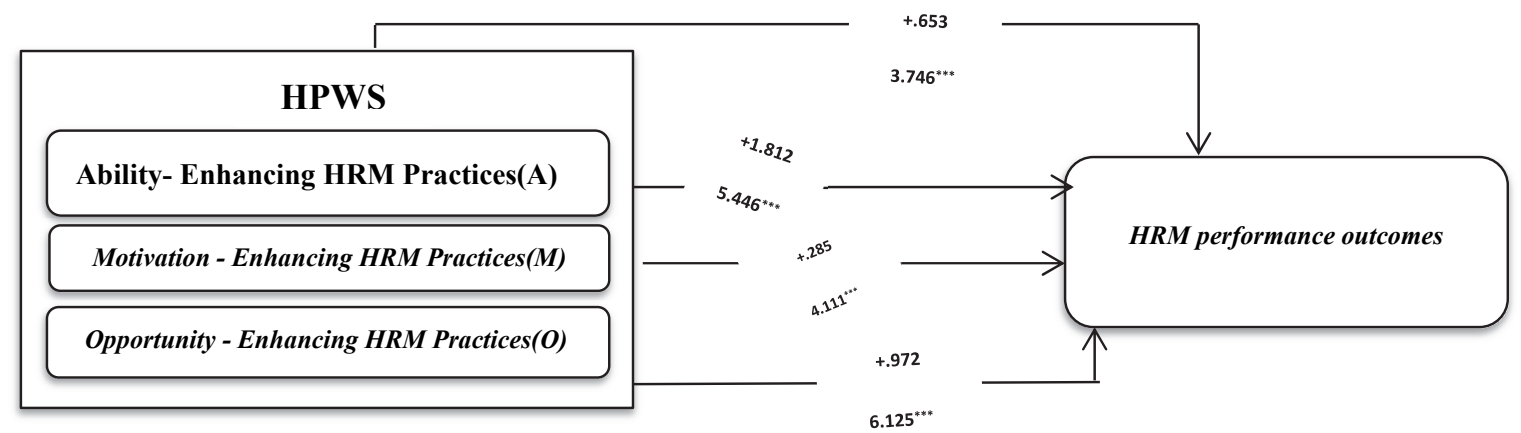

Fig. 3. The proposed conceptuaı model with results

The main hypothesis of the research (H1): There is a significant, statistically significant effect among high-performance work systems according to the (AMO) model on the results of human resources performance ... This hypothesis was accepted, as the results proved that there is a positive and significant effect among high-performance work systems according to For the (AMO) model and the results of human resources performance, where we find that Estimate $=.643$ with a positive sign, which means that there is a positive relationship that is, when increasing the systems of high performance work according to the model (AMO) (the independent variable) with a value of 1.00, the results of the human resources performance (variable) increase The function) by .643 , and vice versa, we also find $\mathrm{CR}=.7463$ which indicates the existence of an effect and a relationship between them where the value exceeds 1.96 in addition to that this relationship is significant because $* * *=\mathrm{P}$, so the hypothesis was accepted. The first sub-hypothesis (H1.1: There is a statistically significant effect between the abilityenhancing HRM practices (training and development, recruitment and selection, performance evaluation) on the results of human resources performance. This hypothesis was accepted, as the results proved that there is an impact Substantial and significant between the ability-enhancing HRM practices (training and development, recruitment and selection, performance evaluation) and the results of human resource performance, as we find that Estimate $=1.812, \mathrm{CR}=.4465, * * *=\mathrm{P}$, so the hypothesis was accepted. The second sub-hypothesis (H1.2): There is a statistically significant effect between HRM practices that enhance motivation (material incentives, job promotion, cooperative climate, job security) on the results of human resources performance. This hypothesis was accepted, as the results proved that there is a positive and significant effect between the ability-enhancing HRM practices (training and development, recruitment and selection, performance evaluation) and the results of human resources performance, as we find that Estimate $=.285, \mathrm{CR}=4.111, * * *=\mathrm{P}$, so it was done. Accept the 
hypothesis. The third sub-hypothesis (H1.3): There is a statistically significant impact between HRM practices that enhance opportunities for participation (quality circles, group work, decision-making, information exchange and communication, job title, job rotation) on HRM performance outcomes. This hypothesis was accepted, as the results proved that there is an indirect and significant effect between the ability-enhancing HRM practices (training and development, recruitment and selection, performance evaluation) and the HRM outcomes performance, as we find that Estimate $=.972, \mathrm{CR}=6.125, * * *=\mathrm{P}$.

\section{Discussion}

The current study proved that the application of high-performance work systems according to the AMO model has a positive and significant effect on the HRM performance outcomes, as the first sub-hypothesis was accepted, as the statistical results proved based on the collected data that there is a positive moral relationship between both HRM practices ability-enhancing (training and development, recruitment and selection, performance appraisal), motivation-enhancing HRM practices (material incentives, job promotion, collaborative climate, job security, HRM practices that enhance opportunities for participation) quality circles, teamwork, decision-making, Information and communication exchange, job title, job rotation) on HRM performance outcomes. The results of this study indicate that the practices of high-HPWS are a ruling factor and positively affect the HRM performance outcomes in all sectors, especially the banking sector (understudy), as it explained $43 \%$ of the variance in performance results in this sector. Several studies (Appelbaum et al. 2000; Block \& Pick1, 2014; Lepak, Han, Hong, Kim \& Winkler, 2012, Knies \& Leisink, 2014; Rabl, Jayasinghe) have documented that there is a positive relationship between HPWS use and business performance. Based on the study prepared by (Appelbaum et al., 2000) on three industries: steel, clothing, and electronic medical tools with the aim of providing a comprehensive picture of effective HPWS, in general, they showed that HPWS has had a positive impact on the organization's performance in each industry and requires three basic components. To use employees' discretionary efforts effectively: the opportunity to participate, appropriate incentives, and policies to develop employees' capabilities and skills. Discretionary behavior refers to an employee's voluntary choice of how to perform his or her tasks. Positive discretionary behaviors are related to "going the extra mile." That is to say, work beyond basic requirements According to the AMO model, discretionary efforts will positively influence organizational performance and employee confidence in their managers, intrinsic job perception, organizational commitment, job satisfaction, and stressrelated to Action. Finally, they also investigated the impact of HPWS on employee earnings, as well as on Hutchinson's productivity growth (2013). The AMO model provides guidance on HRM practices that should be included in a High-Performance Business System (HPWS). Whereas, it is an appropriate mix of different HRM practices rather than individual practices that can ensure that all three components of the AMO model are reinforced and ultimately lead to employee increase or workforce performance Delery and Roumpi (2017). In other words, HRM practices that combine with HPWPs can be viewed as the ability enhancement or skills enhancement, motivation enhancement, opportunity enhancement or empowerment. A high-performance business system manages its valued and talented employees in a way that helps generate a sustainable competitive advantage for the organization (Way, 2002). A high-performance work system affects employees' skills, attitudes, and behavior, which can be useful in creating and developing knowledge within the company. In the same vein, HPWS helps employees create new knowledge and motivate them with learning capabilities in order to enhance the productivity and efficiency of the organization. Zacharatos et al. (2005) asserted that high-performance work systems focus on empowering employees through increased information flow and decentralization of decision-making and are associated with increased employee efficiency. Boxall and Purcell (2003) also argue that high-performance work practices are a combination of key practices such as stricter selection and better training systems to enhance ability levels, and more inclusive incentives (such as employee bonuses and promotion) to increase motivation and participatory structures (self-management teams and quality circles). That improves your chances of contributing. Reduced turnover, increased productivity and quality (MacDuffie, 1995), better service performance (Chuang and Liao, 2010), improved safety performance (Zacharatos et al., 2005) and improved financial performance (Huselid, 1995).

\section{Conclusion}

HPWS positively affects organizational performance. Although there is no consensus on how these systems work and the existence of many models, the researcher suggests that the AMO model is the best-proposed model for improving HRM through literature reviews and analytical study performance outcomes. The current study addressed the conceptual framework of HPWS according to the AMO model as one of the contemporary issues in management, especially in HRM, as it contributes to improving HRM performance outcomes, and this was confirmed by building a hypothetical scheme to study the nature of the relationship between the independent variable HPWS according to AMO and the dependent variable HRM outcomes. The implementation of HPWS is a significant strategic investment of human capital, as the human resource is the most vital and valuable component of competitiveness and survival, so the human resource is the center of attention in HPWS. The current study recommends the need to pay attention to HPWS practices because of their significant impact on performance outcomes and continuous improvement. At the level of ability-enhancing practices: the necessity of subjecting all job applicants to structured interviews, employing individuals who have skills consistent with the values and culture calling for development, innovation and excellence, and setting up planned training programs that help them directly in developing performance. At the level of motivation-enhancing practices: the necessity of establishing systems for the fair evaluation of employee performance, linking the level of wages and competencies with productivity, the promotions system be based on competencies and real knowledge capabilities. At the level of opportunities- enhancing practices: open communication channels between the various administrative levels to have efficiency coordination. Establish an effective and fair system for the complaints and the 
effectiveness of participation from all departments. The need to enhance workers' confidence and make them aware of the roles they play, encourage them to present creative ideas, and empower them with attention to the stimulus chain. Enhancing the database owned by the institution, to organize and disseminate knowledge, with the necessity to provide information promptly, and to ensure that it is appropriate to the needs of the recipient. HPWS needs high efforts to achieve integration between senior management, HRM and all departments of the organization

\section{Acknowledgments}

The authors extend her appreciation to the Deanship of Scientific Research at King Khalid University for funding this work through General Research Project under grant number (GRP/192/42) -2021.

\section{References}

Almutawa, Z., Muenjohn, N., \& Zhang, J. (2016). The effect of human resource management system on employees' commitment: The mediating role of the AMO model. The Journal of Developing Areas, 50(6), 17-29 .

Appelbaum, E., Bailey, T., Berg, P., Kalleberg, A .L., \& Bailey, T. A. (2000). Manufacturing advantage: Why highperformance work systems pay off: Cornell University Press.

Armstrong, M., \& Brown, D. (2019). Strategic Human Resource Management: back to the future. Institute for Employment Studies reports, 1-36.

Bayo-Moriones, A., \& Galdon-Sanchez, J. E. (2010). Multinational companies and high-performance work practices in the Spanish manufacturing industry. The International Journal of Human Resource Management, 21(8), 1248-1271 .

Block, J., \& Pickl, S. (2013). A human resource model for performance optimization to gain competitive advantage, Operations Research Proceedings, 43-48.

Blumberg, M., \& Pringle, C. D. (1982). The missing opportunity in organizational research: Some implications for a theory of work performance. Academy of Management Review, 7(4), 560-569 .

Bos-Nehles, A. C., Van Riemsdijk, M. J., \& Kees Looise, J .(2013) .Employee perceptions of line management performance: applying the AMO theory to explain the effectiveness of line managers' HRM implementation. Human Resource Management, 52(6), 861-877.

Boxall, P. (2003). HR strategy and competitive advantage in the service sector. Human Resource Management Journal, 13(3), $5-20$.

CHUANG, C. H., \& Liao, H. (2010). Strategic human resource management in service context: Taking care of business by taking care of employees and customers. Personnel Psychology, 63(1), 153-196.

Cummings, L. L., \& Schwab, D. P. (1973). Performance in organizations: Determinants \& appraisal :Good Year Books.

Delery, J. E., \& Roumpi, D. (2017). Strategic human resource management, human capital and competitive advantage: is the field going in circles? Human Resource Management Journal, 27(1), 1-21 .

Demirbag, M., Collings ,D. G., Tatoglu, E., Mellahi, K., \& Wood, G. (2014). High-performance work systems and organizational performance in emerging economies: Evidence from MNEs in Turkey. Management International Review, 54(3), 325-359.

Demortier, A.-L. P., Delobbe, N., \& El Akremi, A. (2014). Opening the black box of hr practices-performance relationship: Testing a three pathways AMO model. Paper presented at the Academy of Management Proceedings.

Drummond, I., \& Stone, I. (2007). Exploring the potential of high performance work systems in SMEs. Employee Relations, 29( 2), 192-207.

Edgar, F., Blaker, N. M., \& Everett, A. M. (2020). Gender and job performance: linking the high performance work system with the ability-motivation-opportunity framework. Personnel Review .

Garcia, J. A., \& Tomas, J. M. (2016). Deconstructing AMO framework: A systematic review. Intangible Capital, 12(4), 10401087 .

Gittell, J. H., Seidner, R., \& Wimbush, J. (2010). A relational model of how high-performance work systems work. Organization Science, 21(2), 490-506.

Gong, Y., Chang, S., \& Cheung, S. Y. (2010). High performance work system and collective OCB: A collective social exchange perspective. Human Resource Management Journal, 20(2), 119-137.

Guest, D. E. (1997). Human resource management and performance: a review and research agenda. International Journal of Human Resource Management, 8(3), 263-276.

Hoque, K., Wass, V., Bacon, N \& ,.Jones, M. (2018). Are high-performance work practices (HPWPs) enabling or disabling? Exploring the relationship between selected HPWPs and work-related disability disadvantage. Human Resource Management, 57(2), 499-513 .

Jiang, K., Lepak, D. P., Hu ,J., \& Baer, J. C. (2012). How does human resource management influence organizational outcomes? A meta-analytic investigation of mediating mechanisms. Academy of Management Journal, 55(6), $1264-1294$.

Jyoti, J., \& Rani, A. (2017). High performance work system and organisational performance: Role of knowledge management. Personnel Review, 46(8),1770-1795.

Katou, A. A., \& Budhwar, P. S. (2010). Causal relationship between HRM policies and organisational performance: Evidence from the Greek manufacturing sector. European Management Journal, 28(1), 25-39 . 
Kehoe, R. R., \& Wright, P. M. (2013). The impact of high-performance human resource practices on employees' attitudes and behaviors. Journal of Management, 39(2), 366-391 .

Kim, K. Y., Pathak, S., \& Werner, S. (2015). When do international human capital enhancing practices benefit the bottom line? An ability, motivation, and opportunity perspective. Journal of International Business Studies, 46(7), $784-805$.

Knies, E., \& Leisink, P. (2014). Linking people management and extra-role behavior: results of a longitudinal study. Human Resource Management Journal, 24(1), 57-76.

Lepak, D. P., Liao, H., Chung, Y., \& Harden, E. E. (2006). A conceptual review of human resource management systems in strategic human resource management research. Research in Personnel and Human Resources Management, 25(1), 217271 .

Liao, S.-h., \& Wu, C.C. (2009). The relationship among knowledge management, organizational learning, and organizational performance. International Journal of Business and Management, 4(4), 64-76 .

MacDuffie, J. P. (1995). Human resource bundles and manufacturing performance: Organizational logic and flexible production systems in the world auto industry. Ilr Review, 48(2), 197-221 .

Malik, P., \& Lenka, U. (2019). Exploring the impact of perceived AMO framework on constructive and destructive deviance. International Journal of Manpower .40(5), 994-1011.

Marin-Garcia, J. A., Bayarri, L. R., \& Huerta, L. A. (2015). Protocol: Comparing advantages and disadvantages of Rating Scales, Behavior Observation Scales and Paired Comparison Scales for behavior assessment of competencies in workers. A systematic literature review. WPOM, 6(2), 49-63.

Marin-Garcia, J. A., Miralles, C., Garcia-Sabater, J. J., \& Perello-Marin, M. R. (2011). Alternative tools to mass production and human performance indicators in sheltered work centers of Valencian community (Spain). Journal of Industrial Engineering and Management (JIEM), 4(3), 467-480 .

Minbaeva, D. B. (2013). Strategic HRM in building micro-foundations of organizational knowledge-based performance. Human Resource Management Review, 23(4), 378-390 .

Morales-Sánchez, R., \& Pasamar, S. (2019). How to improve organisational citizenship behavior by combining ability, motivation and opportunity. Employee Relations: The International Journal, 42(2),398-416 .

Muduli, A. (2015). High performance work system, HRD climate and organisational performance: an empirical study. European Journal of Training and Development, 39(3),239-257.

Ozcelik, G., \& Uyargil, C. (2015). A Conceptual Framework For Line Managers'hrm Implementation Effectiveness: Integrating Social Context And Amo Theories. Journal of Business Economics and Finance, 4(2),289-301.

Posthuma, R.A., Campion, M.C., Masimova, M., Michael, A., \& Campion, M.A. (2013). A High Performance Work Practices Taxonomy: Integrating the Literature and Directing Future Research Show less. Journal of Management, 39(5), 11841220 .

Schimansky, S. (2014). The effect of a high-commitment work system on innovative behavior of employees. University of Twente, $3^{\text {rd }}$ IBA Bachelor Thesis Conference, Enschede, The Netherlands.

Sterling, A., \& Boxall, P. (2013). Lean production, employee learning and workplace outcomes: a case analysis through the ability-motivation-opportunity framework. Human Resource Management Journal, 23(3),24-227 .

Vandenabeele, W., Leisink, P., \& Knies, E. (2013). Public value creation and strategic human resource management: Public service motivation as a linking mechanism(Eds), Managing Social Issues. A Public Values Perspective(pp37-54): Edward Elgar Publishing.

Way, S. A. (2002). High performance work systems and intermediate indicators of firm performance within the US small business sector. Journal of Management, 28(6), 765-785.

Wright, P. M., Dunford, B. B., \& Snell, S. A. (2001). Human resources and the resource based view of the firm .Journal of Management, 27(6), 701-721 .

Wright, P. M., \& Kehoe, R. R. (2008). Human resource practices and organizational commitment: A deeper examination. Asia Pacific Journal of Human Resources, 46(1), 6-20.

Zacharatos, A., Barling, J., \& Iverson, R .D. (2005). High-performance work systems and occupational safety. Journal of Applied Psychology, 90(1), 77 .

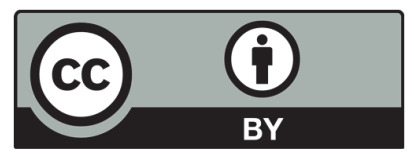

(C) 2021 by the authors; licensee Growing Science, Canada. This is an open access article distributed under the terms and conditions of the Creative Commons Attribution (CC-BY) license (http://creativecommons.org/licenses/by/4.0/). 